\title{
СИНЕРГЕТИЧНИЙ ВПЛИВ РИЗИКІВ ІНВЕСТИЦІЙНОГО ПРОЕКТУ У РОЗРІЗІ ВИДІВ ЕЛЕКТРОГЕНЕРАЦІЇ
}

\author{
СИНЕРГЕТИЧЕСКОЕ ВОЗДЕЙСТВИЕ РИСКОВ ИНВЕСТИЦИОННОГО \\ ПРОЕКТА В РАЗРЕЗЕ ВИДОВ ЭЛЕКТРОГЕНЕРАЦИИ

\section{SYNERGETIC IMPACT OF RISKS OF INVESTMENT PROJECTS IN POWER GENERATION BY THE TYPES}

У статті акцентується увага на важливості проведення оијнювання синергетичного впливу ризиків інвестииійного проекту для різних видів підприємств електрогенерачії під час здійснення якісного аналізу. Проаналізовано науково-методичні підходи щчодо взаємозв'язку ризиків. Аргументовано, щчо вплив ризику на певний проект залежить від характеристик, які властиві конкретному напрямку діяльності підприємства. Продемонстровано розподіл ризиків інвестиційного проекту, які за своїми характеристиками показують належність до окремого виду електрогенерачії. Визначено, щзо один той самий вид ризику інвестиційного проекту має різний набір характеристик в залежності від виду підприємства електроенергетики. На основі методу експертної оцінки проаналізовано синергетичний взаємовплив ризиків інвестиційного проекту окремо для підприємств атомної, теплової та гідравлічної електроенергетики. Встановлено, щзо серед ідентифікованих ризиків найбільший вплив на інші види має політичний ризик.

Ключові слова: підприємства електроенергетики, види електрогенерації, електростанції, інвестиційний проект, ризик-менеджмент, ризик, якісний аналіз, синергетичний вплив.

В статье акцентируется внимание на важности проведения оценки синергетического влияния рисков инвестиционного проекта для различных видов предприятий электрогенеращии при осуществлении качественного анализа. Проанализированы научно-методические подходы к взаимосвязи рисков. Аргументировано, что влияние риска на определенный проект зависит от характеристик, которые присущи конкретному направлению деятельности предприятия. Продемонстрировано распределение рисков инвестиционного проекта, которые по своим характеристикам показывают принадлежность к отдельному виду электрогенерации. Определено, что один и тот же вид риска инвестициионого проекта имеет разный набор характеристик в зависимости от вида предприятия электроэнергетики. На основе метода экспертной оценки проанализированы синергетический взаимовлияние рисков инвестиционного проекта отдельно для предприятий атомной, тепловой и гидравлической электроэнергетики. Установлено, что среди идентифищированных рисков наибольшее влияние на другие виды имеет политический риск.

Ключевые слова: предприятия электроэнергетики, виды электрогенерации, электростанции, инвестиционный проект, риск-менеджмент, риск, качественный анализ, синергетическое воздействие. 
The article focuses on the importance of evaluating the synergistic impact of project risks for different types of power generation companies in the course of qualitative analysis. Scientific and methodological approaches to the relationship risks are analysed. Argued that the impact of risk on a project depends on the characteristics that are inherent in a specific direction of the company. Demonstrated risk-sharing investment project, whose characteristics show affiliation to a particular type of power generation. It was determined that one of the same type of risk investment project has a different set of characteristics depending on the type of the power industry. On the basis of peer review analyses the synergistic interplay of project risks separately for the nuclear, thermal and hydraulic power. Established that among the identified risks greatest impact on other species is political risk.

Keywords: electric power companies, power plants, investment project, risk management, risk synergistic influence.

Вступ. Підприємства електроенергетики як стратегічні об'єкти економіки України потребують першочергової уваги в питаннях підвищення безпеки та поліпшення їх виробничо-комерційної і господарської діяльності. Тому виникає потреба у розробці відповідних цільових інвестиційних програм i проектів 3 технічного переозброєння, модернізації та реконструкції енергетичних потужностей, що базуються на засадах і принципах ризикменеджменту. Адже процес реалізації інвестиційного проекту супроводжується низкою ризиків, що потребують досконального дослідження, аналізу, оцінки і управління. Таким чином, інвестиційний проект (ІП) повинен бути не лише економічно обгрунтованим з точки зору доцільності, але й з точки зору його прийнятного рівня ризикованості.

Теоретичні аспекти управління ризиками в електроенергетиці досліджували такі вітчизняні і зарубіжні науковці як В. О. Бараннік, С. В. Войтко, І. І. Гусєва, Н. М. Денисова, Ю. В. Дронова, А. І. Замілко, В. О. Зубакін, Н. В. Караєва, А. С. Калєсніченко, С. А. Мехович, А. О. Савицька, Л. В. Сорокіна та ін. У розробці теоретичних і методичних засад управління ризиками інвестиційної діяльності на прикладі енергетичних підприємств значний внесок зробили: Г. В. Крамарев, О. А. Крючков, І. М. Манаєнко, Н. А. Пронін, П. В. Нотовський та ін. Однак у наявних наукових роботах $\mathrm{i}$ дослідженнях недостатньо приділено уваги характеристикам ризиків та їх взаємозв'язку між собою у відповідності до специфіки виду електроенергії.

Постановка завдання. Метою статті $\epsilon$ теоретичне та науковометодичне обгрунтування аналізу взаємозв'язку й взаємовпливу різних видів ризиків ІП на основі їх характеристик в залежності від виду виробництва електроенергії (теплова, атомна, гідравлічна). Відповідно до поставленої мети було визначено та вирішено такі завдання: проаналізовано науково-методичні підходи щодо здійснення якісного аналізу ризиків; обгрунтовано необхідність проведення якісного аналізу не лише у виявленні ймовірності виникнення ризиків і їх впливу на IП, але в дослідженні взаємозв'язку уже ідентифікованих ризиків; продемонстровано властивість різних видів ризиків, 
a саме їх характеристик, підприємствам різного виду електрогенерації (атомна, гідравлічна, теплова); на основі експертної оцінки виявлено синергетичний вплив ризиків.

Методологія. У ході проведення дослідження за обраною тематикою були використані такі теоретичні та емпіричні методи наукового пізнання як порівняння - для співставлення ризиків інвестиційних проектів на підприємствах 3 різного виду виробництва електроенергії; абстрагування для виокремлення груп ризиків, які співвідносяться з об'єктом дослідження (інвестиційний проект), а не з суб'єктом (підприємство електроенергетики), аналіз і синтез - для дослідження наукових робіт вчених за даної тематики та виявлення в них недоліків; системний підхід - для визначення характеристик ризиків, які властиві певному направленню діяльності підприємства; експертний підхід - для визначення синергетичного впливу ризиків на різних підприємствах з виробництва електроенергії.

Результати дослідження. У роботі $[1$, с. 500] нами була уточнена процедура ідентифікації ризиків, яка базується на діалектичному взаємозв'язку причин, ризикоутворючих факторів та ризикових ситуацій. Вихідним компонентом є результат реалізації ризику для об'єкту дослідження (у нашому випадку це ІП), який в подальшому узгоджується із конкретним видом ризику. На основі цього у статті [2] була здійснена ідентифікація ризиків ІП. Однак подальше дослідження ідентифікованих ризиків потребує детального аналізу. Аналіз ризику - це процес, який полягає в обробці даних уже виявлених (ідентифікованих) ризиків для визначення їх впливу на проект та розробки подальших засобів й інструментів їх управління.

Опрацьовуючи наукові роботи вчених з напряму дослідження не було виявлено єдиного науково-методичного підходу щодо аналізу ризиків ІП. Проте переважна більшість науковців дотримується загально визначених методів аналізу ризиків таких як якісний та кількісний аналіз. Першочерговим у проведенні $є$ якісний аналіз, а його результати $є$ вихідними даними для кількісного аналізу (оцінки ризиків).

На основі розглянутих наукових праць, нами було визначено, що думки вчених розділилися щодо мети та доцільності здійснення якісного аналізу ризиків. Такі науковці як С. В. Войтко, Л. В. Сорокіна, Е. О. Човушян і М. А. Сідоров вважають, що якісний аналіз полягає у виявленні окремих джерел небезпеки та оцінки їх потенційного впливу на можливі фінансові й фізичні втрати ІП [3, с. с. 106; 4, с. 20]. Н. В. Караєва, І. І. Гусєва, В. О. Бараннік, А. О. Савицька, В. В. Черкасов стверджують, що якісний аналіз має на меті визначити чинники, області й види ризиків [5, с. 116; 6. с. 254]. А такі вчені як П. В. Нотовський та К. С. Радченко формулюють якісний аналіз ризиків як такий, що визначає ступінь ймовірності виникнення ризиків, їх рівня втрат $\mathrm{i}$ впливу на ІП у разі виникнення [7, с. $6 ; 8$, с. 285]. 
На наш погляд, розгляд якісного аналізу ризиків як визначення причин, факторів і видів ризиків не $є$ обгрунтованим, адже виконання таких задач відноситься до процесу ідентифікації ризиків, як окремого етапу ризикменеджменту. Щодо підходу до якісного аналізу, який визначає ймовірність виникнення ризиків і їхнього впливу на ІП в разі настання, то такий підхід $\epsilon$ традиційним в аналізі ризиків ІП, але він не показує взаємозв'язку між конкретними ризиками, тобто у випадку настання одного ризику чи виникає ряд інших.

У ряді робіт вітчизняних та зарубіжних вчених можна зустріти аналіз взаємозв'язку ризиків. Так наприклад, П. В. Нотовський у своїй роботі $[7$, с. 5] пропонує здійснювати аналіз за допомогою впровадженої комплексної класифікації факторів ризиків інвестицій підприємств електроенергетики за двома напрямами: 1. за напрямом взаємодії 3 показниками ефективності (будівельно-операційний, торгівельно-комерційний, альтернативно-часовий, технологічно-часовий); 2 . за соціально кваліфікаційними ознаками (політичний, економічний, соціальний, технічний). Тобто за першим напрямом науковцем розглядається попарний взаємозв'язок ризиків, а за другим окремо кожен вид ризику. Поза увагою лишається вплив кожного ризику на інший вид ризику.

Ознайомившись 3 науковою роботою Ю. В. Дронової $[9$, с. 10], можна відзначити, що автор досліджує взаємозв'язок ризиків, проте розглядаючи ризики на мікро- та макрорівнях, при чому робота присвячена дослідженню безпосередньо ризиків мікрорівня, це зумовлено тим, що на цьому рівні ризики підлягають управлінню. Аналіз взаємозв'язку ризиків грунтується на теорії невизначеності інформації, тобто серед визначених Ю. В. Дроновою ризиків (технологічний, виробничий, економічний, комерційний, ресурсний) виділено один ризик - ресурсний, який через високу ступінь невизначеності інформації впливає на всі інші види ризиків.

Таким чином, проаналізувавши ряд наукових робіт, на нашу думку якісний аналіз повинен полягати не лише у виявленні ймовірності виникнення ризиків i ïx впливу на IП, але в дослідженні взаємозв'язку уже ідентифікованих ризиків, а саме їх впливу один на одного на основі їх характеристик, що стане вихідною інформацією для кількісного аналізу ризиків ІП. Для обгрунтованості нашого підходу пропонуємо розглянути якісний аналіз на основі оцінювання синергетичного взаємовпливу ризиків ІП, в розрізі видів елекрогенерації.

Як уже зазначалося вище, у роботі [2] було здійснено ідентифікацію ризиків ІП, безпосередньо в атомній енергетиці, де ризики було розділено на три ключові групи та описано для кожного виду ризику його передумови виникнення, ризикоутворюючі фактори і ризикові ситуації. До I групи ризиків, які є потенційними джерелами аварійного стану на електростанції 
нами було віднесено: проектний; будівельно-монтажний; технікотехнологічний; кадровий; політичний. До II групи ризиків, які є джерелами фінансових збитків ЕС відносяться: інформаційний; операційний; фінансовий; ринковий; валютний. III група ризиків, які є джерелами збитків завданих 3-тім особам включає: екологічний; радіаційний; соціальний.

Також окремо від цих груп доцільно виокремити ризик стихійних явищ, тобто події, що спричиненні внаслідок природної стихії та можуть призвести одночасно до аварійної ситуації, фінансових збитків і екологічної катастрофи, до них відносяться: аномальне явище, смерч, буря, вихор, шторм, зливові дощі, повінь, град, блискавка, льодохід, надходження підгрунтових вод, зсув, переміщення й осідання грунту, землетрус, обвал, схід лавин тощо $[10$, с. 5].

Однак в ході дослідження виробничо-комерційної та господарської діяльності підприємств тепло- i гідро електроенергетики відмічена закономірність, що ризики першої та другої груп в основному є спільними для AEC, TEC і ГЕС, а відмінність в класифікації видів ризиків третьої групи залежить від виду електрогенерації. Таким чином, визначено, що вплив ризику на реалізацію ІП залежить не лише від його виду, але й від характеристик, які властиві певному направленню діяльності підприємства. Наглядно продемонструємо розподіл ризиків IП, які за своїми характеристиками демонструють належність окремому виду підприємства електрогенерації (табл. 1).

Таблиця 1

Розподіл видів ризиків ІП за характеристиками у відповідності до виду підприємства електрогенерації

\begin{tabular}{|c|c|c|c|c|}
\hline Вид ризику & Характеристика & $\mathrm{AEC}$ & TEC & ГЕC \\
\hline \multicolumn{5}{|c|}{ І група ризиків, які є потенційними джерелами аварійного стану на електростанції } \\
\hline Проектний & $\begin{array}{l}\text { допущення помилок при проектуванні й розробці } \\
\text { окремих комплектуючих, елементів та } \\
\text { управління енергоблоку (ЕБ) чи гідроагрегату (ГА) }\end{array}$ & + & + & + \\
\hline $\begin{array}{l}\text { Будівельно- } \\
\text { монтажний }\end{array}$ & $\begin{array}{l}\text { аварії спричиненні дією вогню (пожежа, удар блискавки, } \\
\text { вибух, збитки понесені під час поширення дим, } \\
\begin{array}{l}\text { виділення сажі, корозійного газу, а також гасіння } \\
\text { пожежі) }\end{array}\end{array}$ & + & + & + \\
\hline $\begin{array}{c}\text { Техніко- } \\
\text { технологічний }\end{array}$ & фізичний та моральний знос основних засобів & + & + & + \\
\hline Кадровий & неефективна система управління персоналом & + & + & + \\
\hline Політичний & $\begin{array}{l}\text { терористичні акти, революційні події, воєнні конфлікти, } \\
\text { політичні заворушення, громадянська війна, зміна влади } \\
\text { та режиму правління всередині країни }\end{array}$ & + & + & + \\
\hline \multicolumn{5}{|c|}{ II група ризиків, які є джерелами фінансових збитків ЕС } \\
\hline
\end{tabular}

Продовження таблииі 1

\begin{tabular}{|l|l|l|l|l|l|}
\hline Інформаційний & $\begin{array}{l}\text { недостатність чи неповнота інформації про район } \\
\text { розміщення й майданчиків під забудову для інженерів- }\end{array}$ & + & + & + \\
\hline
\end{tabular}




\begin{tabular}{|c|c|c|c|c|}
\hline & розробників та проектувальників & & & \\
\hline Операційний & простої в роботі ЕБ чи ГА (порушення графіку роботи) & + & + & + \\
\hline Ринковий & $\begin{array}{l}\text { закупівля палива й необхідного обладнання, } \\
\text { устаткування, машин і програмного забезпечення для ЕС } \\
\text { (зміна цін й умов при закупівлі палива необхідного для } \\
\text { виробництва електроенергії) }\end{array}$ & + & + & + \\
\hline Фінансовий & $\begin{array}{l}\text { порушення строків чи взагалі припинення фінансування } \\
\text { ІП }\end{array}$ & + & + & + \\
\hline Валютний & девальвація / ревальвація національної валюти & + & + & + \\
\hline \multicolumn{5}{|c|}{ III група ризиків, які є джерелами збитків завданих 3-тім особам } \\
\hline \multirow{3}{*}{ Екологічні } & $\begin{array}{l}\text { техногенне-радіоактивне } \\
\text { покриву }\end{array}$ & + & - & - \\
\hline & теплове забруднення та зміни клімату & - & + & - \\
\hline & $\begin{array}{l}\text { перекриття русла рік гідровузлами, створення підпору і } \\
\text { змінення річкових стоків }\end{array}$ & - & - & + \\
\hline Радіаційний & $\begin{array}{l}\text { порушення контролю і управління ланцюжкової реакції } \\
\text { ділення в активній зоні реакторної установки }\end{array}$ & + & - & - \\
\hline \multirow[b]{3}{*}{ Соціальний } & $\begin{array}{l}\text { негативні зміни в стані здоров’я } \\
\text { захворюваності у місцевого населення; }\end{array}$ & + & + & - \\
\hline & $\begin{array}{l}\text { нехтування соціальною відповідальність ЕС та зниження } \\
\text { рівня безпеки життєдіяльності населення в зоні } \\
\text { спостереження; }\end{array}$ & + & + & + \\
\hline & $\begin{array}{l}\text { втрата майна населення (будинки, присадибні ділянки, } \\
\text { ін. будівлі на територія власника) чи його пошкодження } \\
\text { внаслідок аварія на ЕС (аварія на АЕС - зараження } \\
\text { території в 50-км зоні, аварія на ГЕС - затоплення } \\
\text { територій, що знаходяться нижче гідровузлів), } \\
\text { переселення населення в інші місця з зони відчуження } \\
\text { чи зони затоплення }\end{array}$ & + & - & + \\
\hline
\end{tabular}

Табличя подається у скороченому варіанті

3 таблиці 1 видно, що, наприклад, такий вид ризику як екологічний властивий для IП як на $\mathrm{AEC}$, так i TEC i ГЕС, проте лише аналіз його характеристик показує, які саме події потрібно врахувати під час реалізації ІП на кожному окремому підприємстві. А такий вид ризику як радіаційний властивий лише ІП в атомній енергетиці. Аналіз характеристик надає можливості не лише визначити належність до окремого виду підприємства електрогенерації, але й встановити взаємозв’язок між видами ризиків.

Для того, щоб проаналізувати синергетичний вплив ризиків IП підприємств електроенергетики, нами було використано один із методів якісного аналізу - це метод експертних оцінок. Так за результатами опитування кожного експерта була побудована матриця синергетичного впливу ризиків ІП окремо для АЕС (табл. 2), ТЕС і ГЕС. Кожному обраному експерту було подано перелік ризиків 3 їх характеристиками, на основі чого 
експерту необхідно було поставити у відповідну комірку де пересікаються різні види ризиків або 0 - не має впливу, або 1 - має вплив. В кінці навпроти кожного виду ризику виводиться підсумкова оцінка, відповідно чим вища оцінка, тим більший вплив має ризик на інші види.

Таблиця 2

Матриця синергетичного впливу ризиків ІП для АЕС на основі експертної оцінки

\begin{tabular}{|c|c|c|c|c|c|c|c|c|c|c|c|c|c|c|c|}
\hline & 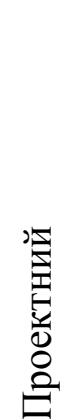 & 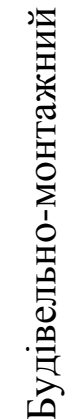 & 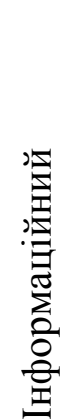 & 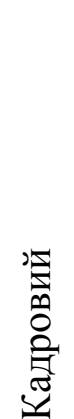 & 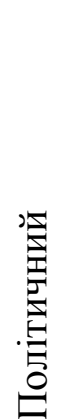 & 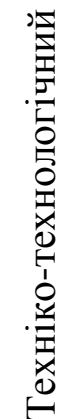 & 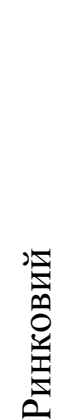 & 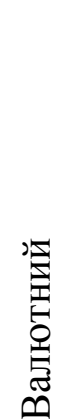 & 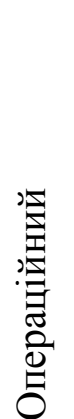 & 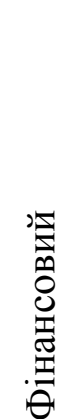 & 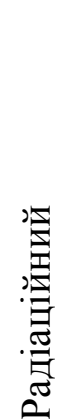 & 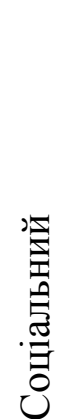 & 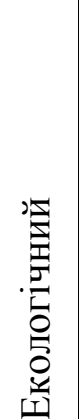 & 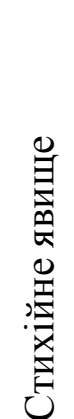 & 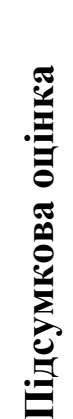 \\
\hline Проектний & - & 1 & 1 & 0 & 0 & 1 & 0 & 0 & 0 & 1 & 1 & 0 & 0 & 0 & 5 \\
\hline $\begin{array}{l}\text { Будівельно- } \\
\text { монтажний }\end{array}$ & 0 & - & 0 & 1 & 0 & 1 & 0 & 0 & 1 & 1 & 1 & 1 & 1 & 0 & 7 \\
\hline Інформаційний & 1 & 1 & - & 1 & 1 & 1 & 1 & 1 & 1 & 1 & 0 & 1 & 0 & 0 & 10 \\
\hline Кадровий & 1 & 1 & 1 & - & 1 & 1 & 0 & 0 & 1 & 1 & 1 & 0 & 1 & 0 & 9 \\
\hline Політичний & 1 & 1 & 1 & 1 & - & 1 & 1 & 1 & 1 & 1 & 1 & 1 & 1 & 0 & 12 \\
\hline $\begin{array}{l}\text { Tехніко- } \\
\text { технологічний }\end{array}$ & 0 & 0 & 0 & 1 & 0 & - & 0 & 0 & 1 & 1 & 1 & 1 & 1 & 0 & 6 \\
\hline Ринковий & 0 & 1 & 0 & 0 & 0 & 1 & - & 1 & 1 & 1 & 0 & 0 & 0 & 0 & 5 \\
\hline Валютний & 0 & 1 & 0 & 0 & 0 & 1 & 1 & - & 1 & 1 & 0 & 0 & 0 & 0 & 5 \\
\hline Операційний & 0 & 1 & 0 & 1 & 1 & 1 & 1 & 1 & - & 1 & 1 & 1 & 1 & 0 & 10 \\
\hline Фінансовий & 1 & 1 & 1 & 1 & 0 & 1 & 1 & 1 & 1 & - & 0 & 0 & 0 & 0 & 8 \\
\hline Радіаційний & 0 & 0 & 0 & 1 & 1 & 1 & 0 & 0 & 1 & 1 & - & 1 & 1 & 0 & 7 \\
\hline Соціальний & 1 & 0 & 0 & 1 & 0 & 1 & 0 & 0 & 1 & 1 & 0 & - & 0 & 0 & 5 \\
\hline Екологічний & 0 & 0 & 0 & 1 & 1 & 1 & 0 & 0 & 1 & 1 & 1 & 1 & - & 0 & 7 \\
\hline Стихійне явище & 0 & 1 & 0 & 0 & 0 & 1 & 1 & 0 & 1 & 1 & 1 & 1 & 1 & - & 8 \\
\hline
\end{tabular}

Для узагальнення результатів нами було побудована порівняльна діаграма синергетичного впливу ризиків ІП для АЕС, ТЕС і ГЕС (рисунок). 3 рисунку випливає, що найбільший вплив на інші види ризиків має політичний ризик - 12 балів для АЕС та 11 балів для ТЕС і ГЕС, також для ГЕС на рівні 3 політичним $€$ інформаційний ризик. Експертами було відмічено, що сьогоденна ситуація в країні $є$ яскравим прикладом виникнення політичного ризику, а також його вплив на інші. Так наприклад внаслідок політичного ризику (воєнні конфлікти на сході країни), призвело до операційного (порушення плану виробництва електроенергії), ринкового (проблеми із закупівлею палива для виробництва електроенергії), фінансового 
(недотримання прибутку підприємствами електроенергетики) та до ряду інших видів ризику.

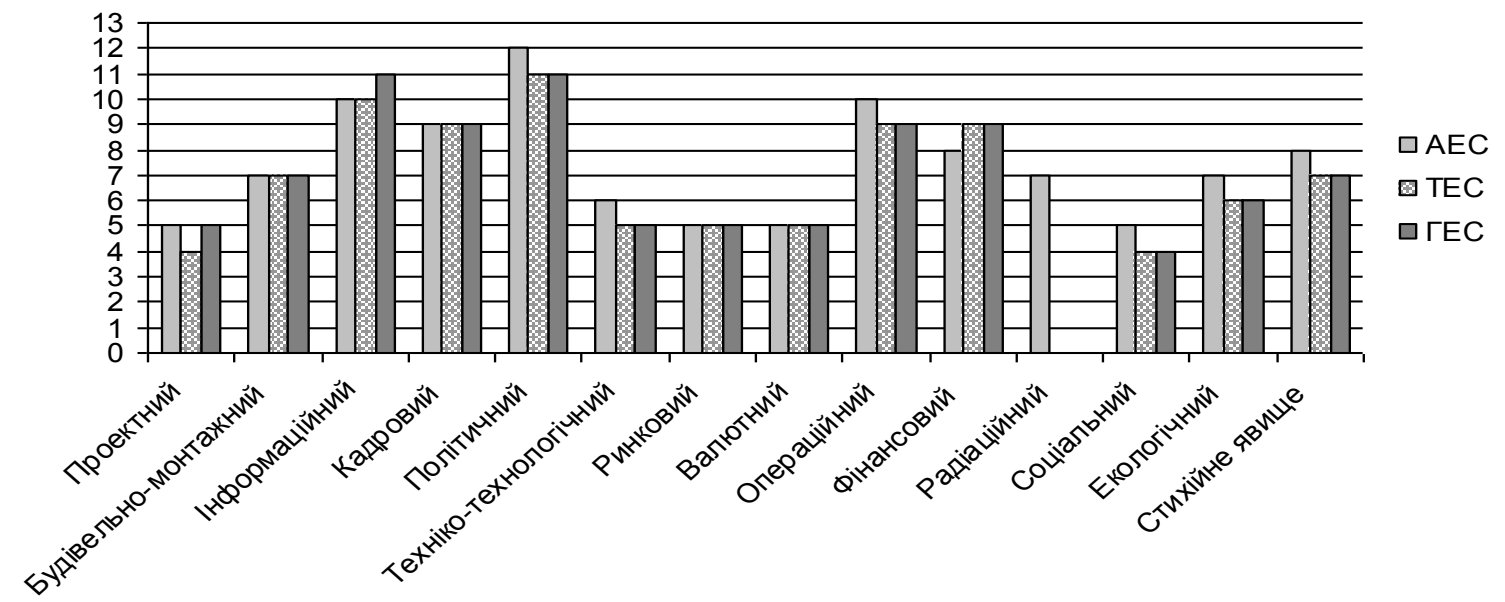

Рисунок. Синергетичний вплив ідентифікованих ризиків ІП для електростанцій

Другими за величиною впливу для АЕC і TEC є інформаційний по 10 балів, операційний 10 балів (АЕС) та 9 балів (ТЕС і ГЕС), фінансовий -9 балів (ТЕС і ГЕС) і 8 балів (АЕС) та кадровий - 9 балів за вагомістю для всіх $\mathrm{EC}$, всі інші мають менший вплив, найнижчий вплив на всі інші види ризиків мають соціальний і проектний ризики.

Таким чином, синергетичний взаємозв'язок між різними видами ризиків показує, що виникнення одного ризику призводить до інших. А тому під час розробки заходів з управління ризиками ІП доцільно розглядати й оцінювати не окремо кожен ризик, а у сукупності з іншими, що у свою чергу надасть можливості вчасно реагувати на найменші прояви одного ризику i мінімізувати відсоток ймовірності настання інших з ним взаємопов'язаних ризиків.

Висновки. Отже, як було зазначено вище успішна реалізація інвестиційного проекту 3 технічного переозброєння, модернізації й реконструкції енергетичних потужностей на електростанціях залежить від низки ризиків, які були розглянуті у статті. Наукова новизна отриманих результатів полягає в удосконаленні процесу якісного аналізу ризиків інвестиційних проектів на підприємствах електроенергетики, що на відміну від відомих методичних і практичних підходів базується на синергетичному взаємовпливі ризиків на основі їх характеристик в залежності від певного виду виробництва електроенергії. Результати якісного аналізу $\epsilon$ вхідною інформацією для кількісного аналізу (оцінки ризиків), що є подальшим напрямом наукових досліджень. 
Практичне значення дослідження полягає у формуванні науковометодичних підходів до аналізу ризиків інвестиційних проектів на підприємствах електроенергетики з метою оптимізації управлінських рішень.

\section{Література:}

1. Охріменко О. О. Ідентифікація ризиків інвестиційних проектів промислових підприємств / О. О. Охріменко, Р. С. Яресько / Економічний вісник НТУУ «КПІ», 2014 (11). - C. 495-501.

2. Яресько Р. С. Ризикологічні аспекти інвестиційного проекту у сфері атомної енергетики / Р. С. Яресько // Бізнес Інформ. - 2014. - № 6. - С. 73-79.

3. Караєва Н. В. Ризик-менеджмент сталого розвитку енергетики: інформаційна підтримка прийняття рішень : навчальний посібник / Н. В. Караєва, С. В. Войтко, Л. В. Сорокіна. — К. : Альфа Реклама, 2013. - 308 с.

4. Човушян Э. О. Управление риском и устойчивое развитие / Э. О. Човушян, М. А. Сидоров. - М. : Издательство РЭА им. Г. В. Плеханова, 1999. - 528 с.

5. Ризик-менеджмент суб'єктів енергетичного ринку як складова механізму забезпечення енергетичної безпеки : монографія / Н. В. Караєва, І. І. Гусєва, В. О. Бараннік, А. О. Савицька. - К. : Софія-А, 2012. -256 с.

6. Черкасов В. В. Проблемы риска в управленческой деятельности : 2-е издание, переработанное и дополненное / В. В. Черкасов. - М. : «Релф-бук» ; К. : «Ваклер», 2002. $317 \mathrm{c}$.

7. Нотовський П. В. Формування стратегій оцінювання ризику інвестицій на підприємствах електроенергетики : автореф. дис. 08.00 .04 - економіка та управління підприємствами (за видами економічної діяльності) / Павло Валентинович Нотовський. Харків, 2013. $-23 \mathrm{c}$.

8. Радченко К. С. Качественный анализ рисков при проектном финансировании / К. С. Радченко // Молодой ученый. - 2013. - №4. - С. 285-287.

9. Дронова Ю. В. Модели оценки производственной деятельности энергетических предприятий : автореф. дис. 08.00 .05 - экономика и управление народным хозяйством (экономика, организация и управление предприятиями, отраслями, комплексами: промышленность) / Дронова Юлия Владимировна. - Новосибирск, 2005. - 24 с.

10. Правила добровільного страхування майна від вогневих ризиків та ризиків стихійних явищ / ЗАТ «Страхова компанія «Українська страхова група». - К., 2009. - 15 с. 